Practice: Between Communities and Classrooms; ed. A. Suresh Canagarajah [Routledge, 2013] 128-38; print). I hope these discussions will stimulate the development of theoretical and pedagogical practices that are better informed and more sensitive to the lived experience of a wide variety of language users.

Paul Kei Matsuda Arizona State University, Tempe

\section{Beauvoir, Colonialism, and Race}

\section{To THE EDITOR:}

In "Simone de Beauvoir and Practical Deliberation" (124.1 [2009]: 199-205), Emily Grosholz argues that "Beauvoir's work exhibits a methodological trajectory as Beauvoir sees more and more clearly that philosophical writing is performative as well as descriptive and that the enterprise she has undertaken is a form of rational persuasion rather than the construction of a 'correct' theory about people" (199). Following Claude Imbert ("Simone de Beauvoir: A Woman Philosopher in the Context of Her Generation"; The Legacy of Simone de Beauvoir; ed. Emily Grosholz [Clarendon, 2004] 3-21; print) and Michèle le Doeuff ("Towards a Friendly, Transatlantic Critique of The Second Sex"; The Legacy of Simone de Beauvoir; ed. Emily Grosholz [Clarendon, 2004] 22-29; print), Grosholz reconstructs the process of Beauvoir's developing analysis of women in the context of Beauvoir's generation. Most important in Beauvoir's work is how she persuaded us to acknowledge the situation of women, specifically those of her generation. Beginning with The Ethics of Ambiguity (1947) and ending with Beauvoir's active engagement with the feminist movement in France, which crystallized around the issue of reproductive rights in the 1970s, Grosholz traces an important tendency in Beauvoir's conception of philosophical method (200).

When Beauvoir led readers to see the untenable contradiction in the estate of women in
The Second Sex (1949), the response brought her public acclaim and notoriety, which enabled her to frame and introduce legislation that at last galvanized feminism in France (203). Focusing on Beauvoir's later political involvement, during the 1970s, Grosholz explains Beauvoir's contribution to the legalization of abortion in France. On 5 April 1971, the "Manifesto of 343" was published

in Le nouvel observateur, signed by a wide range of women who admitted to having had an abortion; Beauvoir was among them. By signing the manifesto, they all risked imprisonment since abortion was illegal; the movement Choisir was created by Gisèle Halimi, a Tunisian practicing as a lawyer in Paris, to defend those women in case they were prosecuted, and Beauvoir was elected its first president.

In 1972 the movement Choisir gained more public acclaim when Halimi, backed by the Women's Liberation Movement in Paris, became involved in the "Bobigny affair." The affair concerned the legal case of a young woman who had been raped and had subsequently undergone an abortion. Through the case, Halimi attacked the 1920 law that criminalized abortion: "she argued that the law punished the poor disproportionately, because rich women had only to cross the English Channel to obtain a legal and safe abortion." The French parliament was influenced by supporters of Choisir-the public, the Women's Liberation Movement in Paris, Beauvoir, Halimi, and Simone Weil-and introduced "law 75-17 in 1975, which legalized the interruption of pregnancy under certain conditions. This law was at first provisional, but a definitive version, law 79-1204, was passed on New Year's Eve 1979" (204). From Grosholz's analysis, we acquire a new sense of the development of Beauvoir's philosophy. Beauvoir came to see that her ethical and political 
writings on the situation of women in France could be used as a practical deliberative tool, an insight that influenced Beauvoir's participation in political movements focusing on the rights of women in France. Beauvoir and her colleagues experienced, in legislation, the concrete possibilities that the actions of women could create for the freedom of women.

Despite my engagement with Grosholz's article, I would like to point out a narrowness of perspective in her approach to Beauvoir's work. Grosholz traces the trajectory of Beauvoir's analysis beginning with Pyrrhus and Cinéas (1944) and culminating in Beauvoir's role in the feminist movement in France, which crystallized around the issue of reproductive rights in the 1970s. Describing this trajectory, Grosholz points to Halimi's influence on Beauvoir's political choices. However, Halimi's influence on Beauvoir's work began much earlier, with Beauvoir's participation in the Djamila Boupacha trial, which began in 1960 (Beauvoir and Halimi; Djamila Boupacha [Gallimard, 1962] 63, 71; print). Boupacha was an Algerian woman who was sentenced to death by the French government for planting bombs in the European quarters of Algeria. By leaving aside Beauvoir's involvement in the trial, Grosholz neglects an important dimension of Beauvoir's analysis, for Beauvoir was concerned not only with gender but also with race and colonialism throughout the 1950s and 1960s. Thus, Grosholz fails to mention how Beauvoir's memoir America Day by Day (1948) influenced Beauvoir's treatment of philosophy as involving performative, descriptive, and deliberative practices. (D. R. Alfonso explores this aspect of the memoir in his article "Transatlantic Perspectives on Race: Simone de Beauvoir's Phenomenology of Race in America Day by Day" [Philosophy Today 49.5 (2005): 89-99; print].) Grosholz is too eager to identify the practical thrust of Beauvoir's writings with feminism; if she had taken into account the racial and colonial influence on Beauvoir's method of approach, she would have been able to make a stronger argument. It is important to see how the intersection of race, colonialism, sex, and gender influenced the deliberative practices that emerged in Beauvoir's philosophy. Like The Second Sex, America Day by Day emphasizes the situation of an oppressed group, black Americans, describes it carefully, and analyzes it as a system of oppression. We can appreciate the depth of her insight, I would argue, when we notice how she combines her perspective on gender with a perspective on racism and the impact of colonialism. Beauvoir's grip on race, colonialism, and gender in combination shows the force of her writing as a form of practical deliberation.

\section{Nathalie Nya \\ Penn State University, University Park}

\section{Reply:}

I acknowledge the main thrust of Nathalie Nya's criticism-that Beauvoir's growing realization that her philosophical writings had practical as well as theoretical import was, one might say, a river fed by many streams. In my essay I discuss the collaboration between Beauvoir and Gisèle Halimi in the early 1970s, when they worked together in the movement Choisir, but Nya reminds us that their work began in 1960, around the trial of Djamila Boupacha. Beauvoir recorded her opposition to French colonialism during the Algerian War in articles published in Les temps modernes over many years, and both she and Sartre received death threats because of their opposition. Nya also reminds us that Beauvoir was profoundly disturbed by the racism she found in the south and in the northern cities of the United States, recorded in her memoir America Day by Day. And her concern for the working class in Europe was expressed in the (misguided) enthusiasm for Soviet and Chinese Marxism she shared with many postwar French intellectuals. Finally, as Claude Imbert explains in the essay cited by Nya, the appalling

(C) 2015 EMILY GROSHOLZ

PMLA 130.1 (2015), published by the Modern Language Association of America 